\title{
Knowledge and attitude of maternity nurses regarding cord blood collection and stem cells: An educational intervention
}

\author{
Hend S. Mohammed ${ }^{1}$, Hend A. EL Sayed $* 2$ \\ ${ }^{1}$ Obstetrics and Gynaecology Nursing, Faculty of Nursing, Zagazig University, Egypt \\ ${ }^{2}$ Obstetrics and Woman Health Nursing, Faculty of Nursing, Benha University, Egypt
}

Received: November 3, 2014

Accepted: January 6, $2015 \quad$ Online Published: January 25, 2015

DOI: $10.5430 /$ jnep.v5n4p58

URL: http://dx.doi.org/10.5430/jnep.v5n4p58

\begin{abstract}
Background: Cord blood collection and stem cell research are the most important and controversial topics of science and technology today. Nurses need to understand stem cell research so they can enter the debate on this issue. Aim was to evaluate the effect of an educational intervention on maternity nurses' knowledge and attitude regarding cord blood collection and stem cells.

Method: Quasi-experimental design (pre and post intervention) was utilized. A total sample of 53 staff nurses were recruited in the study. The study was conducted at two settings; labour unit in obstetrics department at Benha University Hospital and Maternity Hospital at Zagazig University Hospital. Data were collected through two main tools: A structured interviewing questionnaire, and nurses' attitude toward cord blood collection and stem cells.

Results: The results revealed that $88.7 \%$ of nurses had poor knowledge before intervention. However, $90.6 \%$ and $81.2 \%$ of them had good knowledge immediately and after three months of intervention respectively. As well as, only $1.9 \%$ of the studied nurses had positive attitude toward cord blood collection and stem cells before intervention. Meanwhile, immediately and after three months of intervention the positive attitude changed to $66.0 \%$ and $69.8 \%$ respectively.

Conclusion and recommendation: The implementation of an educational intervention was effective and significantly improved nurses' knowledge and attitude towards cord blood collection and stem cells. The study recommended that adequately planned in-service training programs related to cord blood collection and stem cells must established to develop nurses' knowledge, attitude, and practices in order to fit newly developed concepts in care.
\end{abstract}

Key Words: Cord blood collection, Stem cells, Maternity nurses, Educational intervention

\section{Introduction}

Umbilical cord is the vital direct interlink between mother and fetus, which is always depicted as the relationship of an emotional bonding of motherhood, which is a beautiful experience for a women. ${ }^{[1]}$ When mother gives birth, the blood that remains in the placenta and umbilical cord is referred as cord blood. This particular blood contains numerous haematopoietic stem cells that have the ability to differ- entiate into other cells and the ability to self-degenerate. ${ }^{[2]}$

Stem cells are found in all multi cellular organisms, and are characterized by the ability to renew through mitotic cell division and differentiate into a diverse range of specialized cell types. The two broad types of mammalian stem cells are: embryonic stem cells that are isolated from the inner cell mass of blastocysts, and adult stem cells that are found in adult tissues. ${ }^{[3]}$ Cord blood stem cells are pluripotent,

${ }^{*}$ Correspondence: Hend A. EL Sayed; Email: hend.afify@fnur.bu.edu.eg; Address: Obstetrics and Woman Health Nursing, Faculty of Nursing, Benha University, Egypt. 
which is the ability to differentiate into not only different blood cell types, but potentially into different types of tissue including bone, cartilage, hepatic, pancreatic, neurologic, muscle, epithelial, endothelial, and skin. ${ }^{[4]}$

Redefining health in its endeavour to bring a leading edge healing concept is proud to introduce stem cells therapy. Stem cells therapy is the most advanced technology available globally to repair the body's failing system. Umbilical cord blood is increasingly being used as a source of stem cells in the treatment of over 80 diseases, including leukemias, myelomas, lymphomas, genetic disorders/diseases, immune system deficiencies, and blood cell disorders. ${ }^{[5,6]}$

Stem cells from cord blood are much easier to get because these cells are readily obtained from the cord and the placenta at the time of delivery. Similar to cord blood, connective tissue from a section of the umbilical cord can also be collected, preserved, and stored for use in clinical research, donated to a public cord blood bank, or kept in a private cord blood bank for future medical need. Even more than cord blood, Wharton's Jelly, the connective tissue surrounding the umbilical vein and arteries, is a significant source of specific stem cells called mesenchymal stem cells. ${ }^{[7]}$

The stem cells obtained from umbilical cord blood are less likely to be rejected in transplants than bone marrow stem cells. Considered immunologically immature, umbilical cord blood stem cells produce significantly fewer natural killer cells, creating a substantial decrease in rejection, and can be used as a truly ethical therapy. ${ }^{[8,9]}$ Consequently, cord blood stem cells require less rigorous antigen tissue matching for transplants than bone marrow stem cells. Research indicates that a mismatch of up to two antigen sites still provides successful clinical outcomes. ${ }^{[10]}$ In fact, the rate of rejection for cord blood stem cell transplants is half the rate of rejection for bone marrow transplants. When compared directly in cases of mismatched antigens, there was clearly less rejection in transplants involving cord blood stem cells than bone marrow stem cells. ${ }^{[11]}$

Umbilical cord blood collection is primarily carried out by obstetricians, midwives and nurses who have received training in this area. Cord blood is collected by a non-invasive and painless technique after cutting the umbilical cord from the newborn. ${ }^{[12,13]}$ The two methods of cord blood collection in practice are in-utero and ex-utero method, ex-utero method is more commonly used. The in-utero method involves the collection of cord blood after the newborn's delivery but before the delivery of placenta, whereas in the ex-utero method it is collected after the delivery of the placenta. Immediately after the newborn's delivery, the umbilical cord is clamped from the newborn and a needle attached to a collection bag pre-coated with anticoagulant is inserted in the umbilical vein. ${ }^{[14]}$

The nursing role in collection of cord blood is preparation, tube labeling, and packaging. Cord blood is collected using sterile technique, drawing the blood from the umbilical vein into a collection bag, using a closed system collection kit, and total collected volume averages about $110 \mathrm{~mL}$. In some cases, cord blood may be collected into tubes rather than a collection bag, also using sterile technique. In both cases, an anticoagulant is in the collection container. Cord blood collection is done within 10 minutes of birth. ${ }^{[15]}$ Moreover, nurses and midwives are part of health care in all the stages of our lives. Thus, nurses must be knowledgeable and aware of recent trends in diagnosis, treatment. Continuing education provides means by which nurses can remain up to date with current developments, maintain their competence and meet the standards of nursing practice. ${ }^{[16]}$ Nurses are thus challenged to assimilate knowledge, develop critical thinking skills and it is necessary to apply that knowledge into practice. Therefore, nurses need to be educated regarding the value of collecting and preserving umbilical cord blood stem cells for future use in treating illnesses. ${ }^{[17]}$

\subsection{Significance of the study}

Recent advances in science have demonstrated that umbilical cord blood is a rich source of stem cells, making it a valuable tissue resource in the clinical field of stem cell therapy and transplantation. ${ }^{[18]}$ In spite of many benefits of the stem cells obtained from umbilical cord blood, the umbilical cord was considered medical waste and disposed of following delivery along with the placenta due to the lack of knowledge about its the benefits and uses. In addition, from the researchers' clinical experience, they found that there was poor knowledge and negative attitude regarding cord blood collection and stem cells among maternity nurses. Hence, it is imperative to raise nurses' knowledge about recent issues of cord blood collection and stem cells. This study is conducted to improve maternity nurses' knowledge and attitude regarding cord blood collection and its utilization by applying an educational intervention.

\subsection{Aim}

The aim of this study was to evaluate the effect of an educational intervention on maternity nurses' knowledge and attitude regarding cord blood collection and stem cells.

\subsection{Hypotheses}

Maternity nurses who received an educational intervention would have improved knowledge and positive attitude toward cord blood collection and stem cells than before intervention.

\section{Subjects and methods}

\subsection{Research design}

Quasi-experimental design (pre and post intervention) was utilized to fulfil the aim of this study. 


\subsection{Setting}

This study was conducted at two settings; labour unit in Obstetrics Department at Benha University Hospital and Maternity Hospital at Zagazig University Hospital.

\subsection{Sample}

All nurses working in the above mentioned settings at the time of the data collection were included in the study. Total number was 53 staff nurses, they divided into Benha (28) nurses and Zagazig (25) nurses.

\subsection{Tools of data collection}

Two main tools were used for data collection:

\section{I- Structured interviewing questionnaire:}

It was designed by the researchers after reviewing related literature. ${ }^{[15,19]}$ It was written in an Arabic language in the form of close and open-ended questions. It encompassed two major parts:

First part included personal and socio demographic data such as (age, qualifications, and years of experience in delivery room and attendance of training courses about cord blood collection and stem cells.

Second part included nurses' knowledge about cord blood collection and stem cells. It consisted of (4) sections;

- Section (1) general knowledge regarding umbilical cord, it consisted of (5) items (anatomy, physiology, functions, abnormalities, and proper time of clamping umbilical cord).

- Section (2) knowledge pertaining cord blood collection, it consisted of (9) items (definition, benefits, indications, contraindications, appropriate time of collecting cord blood, places for cord blood storage, length of time for cord blood storage, barriers of collecting of cord blood, and responsible persons for collecting cord blood).

- Section (3) knowledge concerning technique of cord blood collection, it consisted of (5) items (methods, preparation, components of collection set, precautions of infection control, and technique of cord blood collection).

- Section (4) knowledge pertaining stem cells, it consisted of (5) items (definition, sites, importance of stem cell from umbilical cord blood, uses, and ethical considerations of obtaining stem cells from umbilical cord).

Scoring: Each item was assigned a score of (2) given when the answer was completely correct, a score (1) was given when the answer was incompletely correct and a score (0) was given when the answer was incorrect or unknown. The total score of each section was calculated by summation of the scores of its items. The total score for the knowledge of nurse was calculated by the addition of the total score of all sections. The mean and standard deviation was calculated. In addition, nurses' total knowledge score was converted into total percent and graded as the following; poor when total score was $(0<16)$, average when total score was $(16<32)$ and good when total score was $(32 \leq 48)$.

\section{II- Nurses attitude towards cord blood collection and stem cells:}

This tool was developed by the researchers after reviewing related literatures, ${ }^{[20,21]}$ to assess nurses attitude pertaining cord blood collection and stem cells and consisted of (16) items such as (Collecting umbilical cord blood immediately after delivery is necessary, cord blood available for life, umbilical cord blood should only be used for baby and his own family ...etc.).

Scoring: The items were judged according to a three point Likert scale continuum from agree (3), neutral (2), and disagree (1). Summing up the scores of the items then the overall score gave total attitude score. Nurses' total attitude score was graded as the following; negative when total score was (16-26), neutral when total score was (27-37) and positive when total score was (38-48).

\subsection{Tools validity and reliability}

Tools were reviewed by a panel of three experts in the field of obstetrics and woman health nursing to test its content validity. Modifications were done accordingly based on their judgment. Reliability was done by Cronbach's Alpha coefficient test which revealed that each of the two tools consisted of relatively homogenous items as indicated by the moderate to high reliability (internal consistency) of each tool (knowledge $=0.92$ and attitude $=0.87)$.

\subsection{Ethical considerations}

An official permission was granted from the directors of the pre mentioned settings. Each nurse was informed about the purpose of the study then a written consent was obtained before starting the data collection. Confidentiality was ensured throughout the study process, and the nurses were assured that all data was used only for research purpose. Each nurse was informed that participation is voluntary and free to withdraw from the study at any time.

\subsection{Pilot study}

The pilot study was carried out on five nurses (about ten percent of the total sample) to test the clarity and applicability of the study tools as well as estimation of the time needed to fill the questionnaire. Required modifications were done in the form of added of some questions as (ethical considerations of obtaining stem cells from umbilical cord...etc.). Nurses involved in the pilot were excluded from the study. 


\subsection{Procedure}

The following phases were adopted to fulfil the aim of the current study; assessment, planning, implementation, and evaluation phases. These phases were carried out from the beginning of July 2012 to the end of April 2013 covering ten months. Official approvals and letters to conduct this research were obtained from dean of researchers faculties to directors of the previous mentioned settings.

\subsubsection{Assessment phase}

This phase encompassed interviewing the nurses to collect baseline data, at the beginning of interview the researchers greeted each nurse, explained the purpose, duration, and activities of the study and taken written consent. Pre-test was done to assess nurses' knowledge and attitude regarding cord blood collection and stem cells. The data obtained during this phase constituted the base line for further comparison to evaluate the effect of an educational intervention. Average time for the completion of each nurse interview was around (30-40 minutes).

\subsubsection{Planning phase}

Based on baseline data obtained from pre-test assessment and relevant review of literature, the educational intervention was developed by the researchers in a form of printed Arabic booklet to satisfy the studied nurses' deficit knowledge, and attitude regarding cord blood collection and stem cells.

General objective of the educational intervention was to improve nurses' knowledge and attitude about cord blood collection and stem cells.

Specific objectives of the educational intervention: after completion of the educational intervention, each nurse should be able to:

- Describe anatomy of umbilical cord.

- Enumerate abnormalities of umbilical cord.

- Discuss physiology of cord blood.

- Mention functions of umbilical cord.

- Identify proper time of clamping umbilical cord and aspirating cord blood.

- Define cord blood collection and stem cells.

- Identify responsible persons for collecting cord blood and benefits of cord blood collection.

- List indications and contraindications of cord blood collection.

- Mention places and length time for cord blood storage.

- Discuss barriers of collecting of cord blood.

- Enumerate uses and sites of obtaining stem cells.

- Discuss the importance of obtaining stem cells from umbilical cord.
- Recognize ethical considerations of obtaining stem cells from umbilical cord.

- Explain methods and preparation steps of umbilical cord blood collection.

- Enumerate components of blood collection set.

- Discuss precautions of infection control during umbilical cord blood collection.

- Describe procedure of aspiration of umbilical cord blood collection.

\subsubsection{Implementation phase}

Implementation of an educational intervention took (20) weeks period. The researchers visited each previous mentioned setting in the two shifts (morning and afternoon), three days/week alternatively. The educational intervention involved (4) scheduled sessions and were implemented according to working circumstances, nurses' physical and mental readiness. These sessions were repeated to each subgroup of (3-5) nurses. The duration of each session lasted from half an hour to one hour including periods of discussion according to their achievement, progress and feedback. At the beginning of the first session an orientation to the educational intervention and its aims took place, Arabic language was used to suit the nurses' level of understanding. Feedback was given in the beginning of each session about the previous one. Different methods of teaching were used such as modified lecture, group discussion and brainstorming. Suitable teaching media were included an educational booklet that distributed to all nurses in the first day of the educational intervention as well as audio-visual aids and real objects such as cord blood collection set, a mannequin and real umbilical cord.

\subsubsection{Evaluation phase}

Immediately and after three months of implementation of the educational intervention, the follow up test for nurses' knowledge and attitude were done by the same format of the pre test to evaluate the effect of the implemented educational intervention.

\subsection{Limitation of the study}

Sometimes the sessions were protracted due to workload, noise and other individuals' interruption that required more time that is devoted and effort. In addition, insufficient number of investigations and review of literature are focusing on nurses' knowledge and attitude regarding cord blood collection and stem cells.

\subsection{Statistical design}

Data were verified prior to computerized entry. The Statistical Package for Social Sciences (SPSS version 20.0) was used. Descriptive statistics were applied (e.g., mean, standard deviation, frequency and percentages). Test of signif- 
icance (chi square and paired $t$ test) was applied to test the study hypothesis. Correlation coefficient was calculated between knowledge, and attitude scores. A statistically significant difference was considered at $p$-value $p \leq .05$, and a highly statistically significant difference was considered at $p$-value $p \leq .001$.

\section{Results}

Table 1 shows socio-demographic characteristics of the studied nurses. It was found that more half of nurses (54.7\%) were aged from 20-25 years, with a mean of age $25.34 \pm 4.51$ years. As far as nurses' qualification, more than half of them $(58.5 \%)$ had diploma. Regarding experience years at delivery room, about two thirds of nurses (62.3\%), their experience ranged from 5-10 years, with a mean of $6.36 \pm 2.75$ years. Only $1.9 \%$ of nurses were attended training courses about cord blood collection and stem cells.

Table 2 illustrates nurses' knowledge about umbilical cord. It was found that $(13.2 \%, 5.7 \%, 3.8 \%, 20.8 \%$, and $28.3 \%)$ of nurses had correctly complete answers before intervention regarding umbilical cord (anatomy, abnormalities, physiology, functions and proper time of clamping umbilical cord), this percentage increased to $(81.1 \%, 79.2 \%, 77.3 \%, 92.5 \%$, and $98.1 \%$ ) respectively at immediately after intervention and slightly decreased to $(66.0 \%, 73.6 \%, 71.7 \%, 83.0 \%$, and $94.3 \%$ ) respectively after three months of intervention and there was highly statistically significant difference at different times of assessment .

Table 1: Distribution of the studied sample according to their general characteristics $(\mathrm{n}=53)$

\begin{tabular}{|c|c|c|}
\hline Characteristics parameters & No & $\%$ \\
\hline \multicolumn{3}{|l|}{ Age (years) } \\
\hline$<20$ & 8 & 15.1 \\
\hline $20-25$ & 29 & 54.7 \\
\hline $26-30$ & 11 & 20.8 \\
\hline$>30$ & 5 & 9.4 \\
\hline Mean \pm SD & $25.34 \pm 4.51$ & \\
\hline \multicolumn{3}{|l|}{ Qualification } \\
\hline Diploma & 31 & 58.5 \\
\hline Diploma + specialty & 9 & 17.0 \\
\hline Technical Nursing Institute & 7 & 13.2 \\
\hline Bachelor of nursing & 6 & 11.3 \\
\hline \multicolumn{3}{|c|}{ Years of experience in delivery room } \\
\hline$<5$ & 16 & 30.2 \\
\hline $5-10$ & 33 & 62.3 \\
\hline$>10$ & 4 & 7.5 \\
\hline Mean \pm SD & $6.36 \pm 2.75$ & \\
\hline \multicolumn{3}{|c|}{ Attendance of training courses about cord blood collection and stem cells } \\
\hline Yes & 1 & 1.9 \\
\hline No & 52 & 98.1 \\
\hline
\end{tabular}

Table 2: Distribution of the studied sample according to their knowledge regarding umbilical cord at different times of assessment $(\mathrm{n}=53)$

\begin{tabular}{|c|c|c|c|c|c|c|c|c|}
\hline \multirow[t]{2}{*}{ Times of assessment } & \multicolumn{2}{|c|}{ Before } & \multicolumn{2}{|c|}{ Immediately after } & \multicolumn{2}{|c|}{ After 3 months } & \multirow{2}{*}{$\chi^{2}$} & \multirow{2}{*}{$P$ value } \\
\hline & No & $\%$ & No & $\%$ & No & $\%$ & & \\
\hline \multicolumn{9}{|l|}{ Anatomy of umbilical cord } \\
\hline Correctly complete & 7 & 13.2 & 43 & 81.1 & 35 & 66.0 & 85.268 & \multirow{3}{*}{$<.001^{* *}$} \\
\hline Correctly incomplete & 15 & 28.3 & 10 & 18.9 & 17 & 32.1 & & \\
\hline Don’t know & 31 & 58.5 & 0 & 0.0 & 1 & 1.9 & & \\
\hline \multicolumn{9}{|l|}{ Abnormalities of umbilical cord } \\
\hline Correctly complete & 3 & 5.7 & 42 & 79.2 & 39 & 73.6 & 88.146 & \multirow{3}{*}{$<.001^{* *}$} \\
\hline Correctly incomplete & 19 & 35.8 & 10 & 18.9 & 12 & 22.6 & & \\
\hline Don’t know & 31 & 58.5 & 1 & 1.9 & 2 & 3.8 & & \\
\hline \multicolumn{9}{|l|}{ Physiology of cord blood } \\
\hline Correctly complete & 2 & 3.8 & 41 & 77.3 & 38 & 71.7 & 87.052 & \multirow{3}{*}{$<.001 * *$} \\
\hline Correctly incomplete & 14 & 26.4 & 9 & 17.0 & 11 & 20.8 & & \\
\hline Don't know & 37 & 69.8 & 3 & 5.7 & 4 & 7.5 & & \\
\hline \multicolumn{9}{|l|}{ Functions of umbilical cord } \\
\hline Correctly complete & 11 & 20.8 & 49 & 92.5 & 44 & 83.0 & 72.882 & \multirow{3}{*}{$<.001^{* *}$} \\
\hline Correctly incomplete & 36 & 67.9 & 4 & 7.5 & 9 & 17.0 & & \\
\hline Don’t know & 6 & 11.3 & 0 & 0.0 & 0 & 0.0 & & \\
\hline \multicolumn{9}{|l|}{ Proper time of clamping umbilical cord } \\
\hline Correctly complete & 15 & 28.3 & 52 & 98.1 & 50 & 94.3 & 86.538 & \multirow{3}{*}{$<.001 * *$} \\
\hline Correctly incomplete & 14 & 26.4 & 1 & 1.9 & 3 & 5.7 & & \\
\hline Don’t know & 24 & 45.3 & 0 & 0.0 & 0 & 0.0 & & \\
\hline
\end{tabular}

$(* *)$ A highly statistical significant difference $(P \leq .001)$ 
Table 3 displays that there was highly statistically significant efits, indications, contraindications, appropriate time of coldifference before, immediately, and after three months of lecting cord blood, places for cord blood storage, length of implementing educational intervention in relation to nurses' time for cord blood storage, barriers of collecting of cord knowledge regarding cord blood collection (definition, ben- blood, and responsible persons for collecting cord blood).

Table 3: Distribution of the studied sample according to their knowledge regarding cord blood collection at different times of assessment $(n=53)$

\begin{tabular}{|c|c|c|c|c|c|c|c|c|}
\hline \multirow[t]{2}{*}{ Times of assessment } & \multicolumn{2}{|c|}{ Before } & \multicolumn{2}{|c|}{ Immediately after } & \multicolumn{2}{|c|}{ After 3 months } & \multirow{2}{*}{$\chi^{2}$} & \multirow{2}{*}{$P$ value } \\
\hline & No & $\%$ & No & $\%$ & No & $\%$ & & \\
\hline \multicolumn{9}{|l|}{ Definition of cord blood collection } \\
\hline Correctly complete & 2 & 3.8 & 44 & 83.0 & 37 & 69.8 & & \\
\hline Correctly incomplete & 19 & 35.8 & 9 & 17.0 & 16 & 30.2 & 104.193 & $<.001 * *$ \\
\hline Don’t know & 32 & 60.4 & 0 & 0.0 & 0 & 0.0 & & \\
\hline \multicolumn{9}{|l|}{ Benefits of cord blood collection } \\
\hline Correctly complete & 4 & 7.5 & 42 & 79.2 & 33 & 62.3 & & \\
\hline Correctly incomplete & 14 & 26.4 & 11 & 20.8 & 19 & 35.8 & 98.343 & $<.001 * *$ \\
\hline Don’t know & 35 & 66.0 & 0 & 0.0 & 1 & 1.9 & & \\
\hline \multicolumn{9}{|l|}{ Indications of cord blood collection } \\
\hline Correctly complete & 0 & 0.0 & 41 & 77.4 & 33 & 62.3 & & \\
\hline Correctly incomplete & 16 & 30.2 & 12 & 22.6 & 18 & 34.0 & 106.130 & $<.001 * *$ \\
\hline Don’t know & 37 & 69.8 & 0 & 0.0 & 2 & 3.8 & & \\
\hline \multicolumn{9}{|c|}{ Contraindications of cord blood collection } \\
\hline Correctly complete & 0 & 0.0 & 39 & 73.6 & 32 & 60.4 & & \\
\hline Correctly incomplete & 9 & 17.0 & 12 & 22.6 & 17 & 32.1 & 106.474 & $<.001 * *$ \\
\hline Don’t know & 44 & 83.0 & 2 & 3.8 & 4 & 7.5 & & \\
\hline \multicolumn{9}{|c|}{ Appropriate time of collecting cord blood } \\
\hline Correctly complete & 6 & 11.3 & 51 & 96.2 & 42 & 79.2 & & \\
\hline Correctly incomplete & 18 & 34.0 & 2 & 3.8 & 11 & 20.8 & 104.815 & $<.001 * *$ \\
\hline Don’t know & 29 & 54.7 & 0 & 0.0 & 0 & 0.0 & & \\
\hline \multicolumn{9}{|l|}{ Places for cord blood storage } \\
\hline Correctly complete & 0 & 0.0 & 44 & 83.0 & 33 & 62.3 & & \\
\hline Correctly incomplete & 13 & 24.5 & 8 & 15.1 & 16 & 30.2 & 106.306 & $<.001 * *$ \\
\hline Don't know & 40 & 75.5 & 1 & 1.9 & 4 & 7.5 & & \\
\hline \multicolumn{9}{|c|}{ Length of time for cord blood storage } \\
\hline Correctly complete & 0 & 0.0 & 43 & 81.1 & 39 & 73.6 & & \\
\hline Correctly incomplete & 5 & 9.4 & 7 & 13.2 & 8 & 15.1 & 108.624 & $<.001 * *$ \\
\hline Don't know & 48 & 90.6 & 3 & 5.7 & 6 & 11.3 & & \\
\hline \multicolumn{9}{|l|}{ Barriers of collecting of cord blood } \\
\hline Correctly complete & 0 & 0.0 & 42 & 79.2 & 36 & 67.9 & & \\
\hline Correctly incomplete & 9 & 17.0 & 10 & 18.9 & 12 & 22.6 & 107.864 & $<.001 * *$ \\
\hline Don’t know & 44 & 83.0 & 1 & 1.9 & 5 & 9.4 & & \\
\hline \multicolumn{9}{|c|}{ Responsible persons for collecting cord blood } \\
\hline Correctly complete & 8 & 15.1 & 52 & 98.1 & 47 & 88.7 & & \\
\hline Correctly incomplete & 12 & 22.6 & 1 & 1.9 & 6 & 11.3 & 108.121 & $<.001 * *$ \\
\hline Don't know & 33 & 62.3 & 0 & 0.0 & 0 & 0.0 & & \\
\hline
\end{tabular}

$(* *)$ A highly statistical significant difference $(P \leq .001)$ 
Table 4 represents that there was highly statistically signifi- ical cord blood collection, components of blood collection cant difference before, immediately, and after three months of implementing educational intervention in relation to nurses' knowledge pertaining technique of cord blood collection and stem cells (methods and preparations of umbilset, precautions of infection control, and procedure of aspiration, definition of stem cells, sites, importance, uses, and ethical considerations of obtaining stem cells from umbilical cord).

Table 4: Distribution of the studied sample according to their knowledge about technique of cord blood collection and stem cells at different times of assessment $(n=53)$

\begin{tabular}{|c|c|c|c|c|c|c|c|c|}
\hline \multirow[t]{2}{*}{ Times of assessment } & \multicolumn{2}{|c|}{ Before } & \multicolumn{2}{|c|}{ Immediately after } & \multicolumn{2}{|c|}{ After 3 months } & \multirow{2}{*}{$\chi^{2}$} & \multirow{2}{*}{$P$ value } \\
\hline & No & $\%$ & No & $\%$ & No & $\%$ & & \\
\hline \multicolumn{9}{|l|}{ Methods of umbilical cord blood collection } \\
\hline Correctly complete & 0 & 0.0 & 41 & 77.4 & 36 & 67.9 & & \\
\hline Correctly incomplete & 2 & 3.8 & 9 & 17.0 & 12 & 22.6 & 120.840 & $<.001 * *$ \\
\hline Don't know & 51 & 96.2 & 3 & 5.7 & 5 & 9.4 & & \\
\hline \multicolumn{9}{|c|}{ Preparations of umbilical cord blood collection } \\
\hline Correctly complete & 0 & 0.0 & 45 & 84.9 & 39 & 73.6 & & \\
\hline Correctly incomplete & 11 & 20.8 & 8 & 15.1 & 12 & 22.6 & 120.027 & $<.001 * *$ \\
\hline Don’t know & 42 & 79.2 & 0 & 0.0 & 2 & 3.8 & & \\
\hline \multicolumn{9}{|l|}{ Components of blood collection set } \\
\hline Correctly complete & 0 & 0.0 & 40 & 75.5 & 34 & 64.2 & & \\
\hline Correctly incomplete & 5 & 9.4 & 13 & 24.5 & 16 & 30.2 & 128.494 & $<.001^{* *}$ \\
\hline Don't know & 48 & 90.6 & 0 & 0.0 & 3 & 5.7 & & \\
\hline \multicolumn{9}{|l|}{ Precautions of infection control } \\
\hline Correctly complete & 15 & 28.3 & 51 & 96.2 & 42 & 79.2 & & \\
\hline Correctly incomplete & 20 & 37.7 & 2 & 3.8 & 11 & 20.8 & 70.227 & $<.001 * *$ \\
\hline Don't know & 18 & 34.0 & 0 & 0.0 & 0 & 0.0 & & \\
\hline \multicolumn{9}{|l|}{ Technique of cord blood collection } \\
\hline Correctly complete & 0 & 0.0 & 38 & 71.7 & 31 & 58.5 & & \\
\hline Correctly incomplete & 2 & 3.8 & 11 & 20.8 & 17 & 32.1 & 119.065 & $<.001^{* *}$ \\
\hline Don’t know & 51 & 96.2 & 4 & 7.5 & 5 & 9.4 & & \\
\hline \multicolumn{9}{|l|}{ Definition of stem cells } \\
\hline Correctly complete & 2 & 3.8 & 44 & 83.0 & 40 & 75.5 & & \\
\hline Correctly incomplete & 15 & 28.3 & 9 & 17.0 & 12 & 22.6 & 107.151 & $<.001 * *$ \\
\hline Don’t know & 36 & 67.9 & 0 & 0.0 & 1 & 1.9 & & \\
\hline \multicolumn{9}{|l|}{ Sites of obtaining stem cells } \\
\hline Correctly complete & 0 & 0.0 & 40 & 75.5 & 34 & 64.2 & & \\
\hline Correctly incomplete & 18 & 34.0 & 12 & 22.6 & 17 & 32.1 & 98.154 & $<.001 * *$ \\
\hline Don’t know & 35 & 66.0 & 1 & 1.9 & 2 & 3.8 & & \\
\hline \multicolumn{9}{|c|}{ Importance of obtaining stem cells from umbilical cord } \\
\hline Correctly complete & 0 & 0.0 & 38 & 71.7 & 30 & 56.6 & & \\
\hline Correctly incomplete & 3 & 5.7 & 10 & 18.9 & 17 & 32.1 & 110.163 & $<.001 * *$ \\
\hline Don't know & 50 & 94.3 & 5 & 9.4 & 6 & 11.3 & & \\
\hline \multicolumn{9}{|l|}{ Uses of stem cells } \\
\hline Correctly complete & 2 & 3.8 & 43 & 81.1 & 38 & 71.7 & & \\
\hline Correctly incomplete & 11 & 20.8 & 10 & 18.9 & 13 & 24.5 & 109.152 & $<.001 * *$ \\
\hline Don't know & 40 & 75.5 & 0 & 0.0 & 2 & 3.8 & & \\
\hline \multicolumn{9}{|c|}{ Ethical considerations of obtaining stem cells from umbilical cord } \\
\hline Correctly complete & 0 & 0.0 & 39 & 73.6 & 32 & 60.4 & & \\
\hline Correctly incomplete & 8 & 15.1 & 14 & 26.4 & 20 & 37.7 & 127.809 & $<.001 * *$ \\
\hline Don't know & 45 & 84.9 & 0 & 0.0 & 1 & 1.9 & & \\
\hline
\end{tabular}


Table 5 reflects that, there was a general improvement in all items of knowledge about umbilical cord, cord blood collection, technique of cord and stem cell blood collection of the studied nurses immediately after educational intervention as compared to before educational intervention. How- ever, a slight mean decline occurred after three months of educational intervention with highly statistically significant difference at $p$-values $<.001$. Nevertheless, the scores were still higher than the before intervention baseline scores.

Table 5: Mean subtotal and total knowledge scores of the studied sample at different times of assessment $(\mathrm{n}=53)$

\begin{tabular}{|c|c|c|c|c|c|c|c|c|}
\hline \multirow[b]{2}{*}{ Knowledge about } & \multirow{2}{*}{$\begin{array}{l}\text { Maximum } \\
\text { Score }\end{array}$} & \multirow{2}{*}{$\begin{array}{l}\text { Before } \\
\text { Mean } \pm \text { SD }\end{array}$} & \multirow{2}{*}{$\begin{array}{l}\text { Immediately } \\
\text { after } \\
\text { Mean } \pm \text { SD }\end{array}$} & \multirow{2}{*}{$\begin{array}{l}\text { Paired } \\
t_{1} \text { test }\end{array}$} & \multirow{2}{*}{$\begin{array}{l}p \\
\text { value }\end{array}$} & \multirow{2}{*}{$\begin{array}{l}\text { After } 3 \text { months } \\
\text { Mean } \pm \text { SD }\end{array}$} & \multirow{2}{*}{$\begin{array}{l}\text { Paired } \\
t_{2} \text { test }\end{array}$} & \multirow{2}{*}{$\begin{array}{l}p \\
\text { value }\end{array}$} \\
\hline & & & & & & & & \\
\hline Umbilical cord & 10 & $3.28 \pm 2.05$ & $9.21 \pm 1.04$ & 16.354 & $<.001 * *$ & $8.73 \pm 1.29$ & 23.012 & $<.001 * *$ \\
\hline Cord blood collection & 18 & $2.92 \pm 2.64$ & $16.36 \pm 1.63$ & 18.284 & $<.001 * *$ & $14.85 \pm 1.71$ & 27.937 & $<.001^{* *}$ \\
\hline $\begin{array}{l}\text { Technique of cord blood } \\
\text { collection }\end{array}$ & 10 & $1.32 \pm 1.22$ & $8.92 \pm 1.21$ & 37.750 & $<.001 * *$ & $7.81 \pm 1.49$ & 31.321 & $<.001 * *$ \\
\hline Stem cell & 10 & $1.19 \pm 1.03$ & $8.74 \pm 1.33$ & 27.149 & $<.001 * *$ & $7.91 \pm 1.43$ & 33.416 & $<.001 * *$ \\
\hline Total & 48 & $8.72 \pm 5.95$ & $43.23 \pm 4.15$ & 41.919 & $<.001 * *$ & $39.79 \pm 3.95$ & 34.768 & $<.001 * *$ \\
\hline
\end{tabular}

$(* *)$ A highly statistical significant difference $(P \leq .001)$; Paired $t_{1}$ test (between before and immediately after); Paired $t_{2}$ test (between before and after 3 months)

Figure 1 illustrates that, most of the nurses $(88.7 \%)$ had poor knowledge level before intervention. However, immediately after intervention, the majority of them (90.6\%) got good knowledge level that declined to $81.2 \%$ after three months of intervention.

Table 6 demonstrates low levels of agreement upon all positive statements before intervention. However, immediately and after three months of intervention phases showed improvements in all items towards nurses' attitude pertaining cord blood collection and stem cells, with highly statistically significant difference before, immediately, and after three months of implementing educational intervention.

Figure 2 illustrates that, only $1.9 \%$ had positive attitude toward cord blood collection and stem cells before intervention. Meanwhile, immediately and after three months of intervention the positive attitude changed to $(66.0 \%)$ and $(69.8 \%)$ respectively.

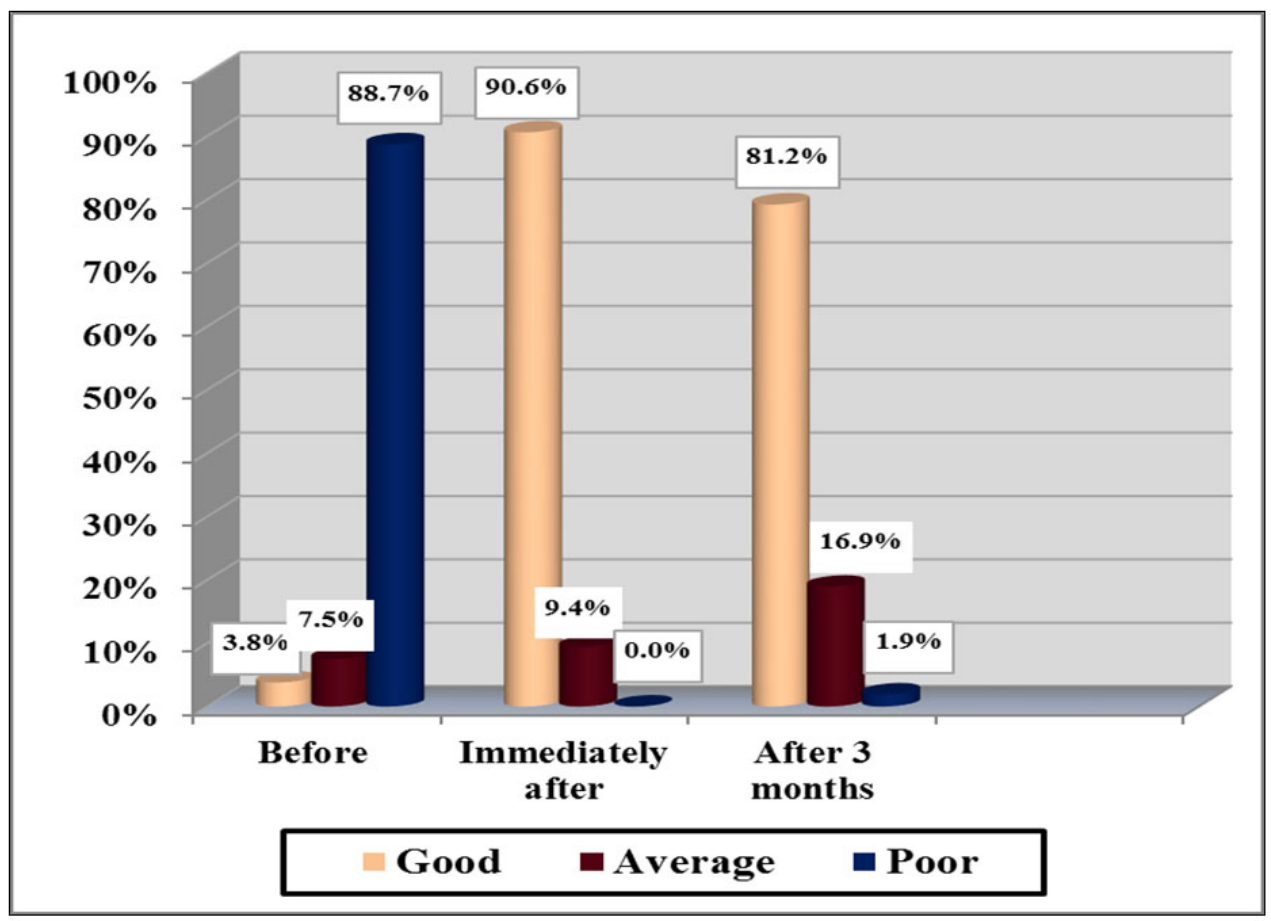

Figure 1: Distribution of the studied sample according to their total knowledge scores at the different times of assessment $(n=53)$ 
Table 6: Distribution of the studied sample according to their attitude toward cord blood collection and stem cells at different times of assessment $(n=53)$

\begin{tabular}{|c|c|c|c|c|c|c|c|c|}
\hline \multirow{3}{*}{ Attitude items } & \multicolumn{6}{|c|}{ Attitude ( Agree) } & \multirow{3}{*}{$\chi^{2}$} & \multirow{3}{*}{$P$ value } \\
\hline & \multicolumn{2}{|c|}{ Before } & \multicolumn{2}{|c|}{ Immediately after } & \multicolumn{2}{|c|}{ After 3 months } & & \\
\hline & No & $\%$ & No & $\%$ & No & $\%$ & & \\
\hline $\begin{array}{l}\text { Collecting umbilical cord blood immediately after delivery } \\
\text { is necessary. }\end{array}$ & 2 & 3.8 & 25 & 47.2 & 28 & 52.8 & 56.133 & $<.001 * *$ \\
\hline Cord blood available for life & 1 & 1.9 & 37 & 69.8 & 38 & 71.7 & 81.144 & $<.001 * *$ \\
\hline $\begin{array}{l}\text { Umbilical cord blood should only be used for baby and his } \\
\text { own family }\end{array}$ & 32 & 60.4 & 5 & 9.4 & 14 & 26.4 & 68.758 & $<.001 * *$ \\
\hline When cord blood is taken, the baby is not harmed at all. & 2 & 3.8 & 43 & 81.1 & 40 & 75.5 & 80.882 & $<.001 * *$ \\
\hline Obtaining cord blood collection is wasting time. & 29 & 54.7 & 1 & 1.9 & 4 & 7.5 & 86.890 & $<.001 * *$ \\
\hline $\begin{array}{l}\text { Concerned that the baby's cord blood would be used for } \\
\text { different purposes. }\end{array}$ & 8 & 15.1 & 43 & 81.1 & 39 & 73.6 & 65.159 & $<.001 * *$ \\
\hline $\begin{array}{l}\text { Believe that everyone can benefit from collected cord } \\
\text { blood and stem cells. }\end{array}$ & 6 & 11.3 & 41 & 77.3 & 39 & 73.6 & 76.871 & $<.001 * *$ \\
\hline $\begin{array}{l}\text { The collection of cord blood affect the care of mother or } \\
\text { her newborn }\end{array}$ & 15 & 28.3 & 2 & 3.8 & 1 & 1.9 & 69.186 & $<.001^{* *}$ \\
\hline $\begin{array}{l}\text { Umbilical cord blood collection should be included as a } \\
\text { routine care in delivery rooms }\end{array}$ & 0 & 0.0 & 32 & 60.4 & 30 & 56.6 & 52.329 & $<.001 * *$ \\
\hline $\begin{array}{l}\text { Experiences and proficiency is required for cord blood } \\
\text { collection }\end{array}$ & 9 & 17.0 & 49 & 92.5 & 44 & 83.0 & 79.998 & $<.001 * *$ \\
\hline $\begin{array}{l}\text { Think it is necessary to perform stem cells cross matching } \\
\text { before use }\end{array}$ & 26 & 49.1 & 47 & 88.7 & 45 & 84.9 & 28.831 & $<.001 * *$ \\
\hline Think it is necessary to have baby's cord blood stored. & 9 & 17.0 & 33 & 62.3 & 38 & 71.7 & 46.403 & $<.001 * *$ \\
\hline $\begin{array}{l}\text { It is necessary to introduce cord blood collection and stem } \\
\text { cells in nursing courses. }\end{array}$ & 22 & 41.5 & 48 & 90.6 & 42 & 79.2 & 42.684 & $<.001 * *$ \\
\hline $\begin{array}{l}\text { It is necessary to cord blood banking for storage of stem } \\
\text { cells. }\end{array}$ & 3 & 5.7 & 34 & 64.1 & 37 & 69.8 & 55.860 & $<.001^{* *}$ \\
\hline $\begin{array}{l}\text { Accept to attend workshops about umbilical cord blood } \\
\text { collection and stem cells. }\end{array}$ & 12 & 22.6 & 49 & 92.5 & 47 & 88.7 & 79.467 & $<.001 * *$ \\
\hline $\begin{array}{l}\text { Collecting umbilical cord blood and stem cells is approved } \\
\text { by religious. }\end{array}$ & 4 & 7.5 & 29 & 54.8 & 24 & 45.3 & 49.926 & $<.001^{* *}$ \\
\hline
\end{tabular}

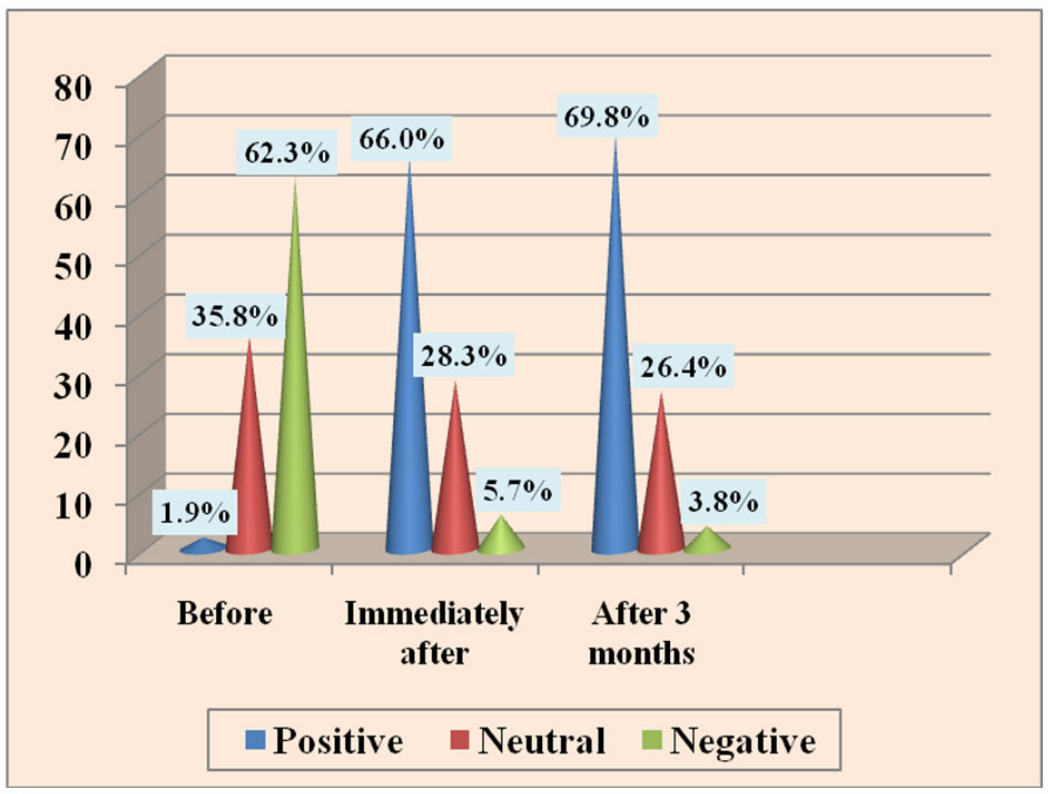

Figure 2: Distribution of the studied sample according to their total attitude level at the different times of assessment $(\mathrm{n}=$ 53) 
Table 7 shows that, there was a negative statistically significant correlation between total knowledge, total attitude scores and age, as well as between total knowledge, total attitude scores and years of experience at different times of assessment. On the other hand, there was a positive statis- tically significant correlation total knowledge, total attitude scores and educational level. Moreover, there was a positive statistically significant correlation between total knowledge score and, total attitude score at different times of assessment.

Table 7: Correlation coefficient between total knowledge, attitude scores regarding cord blood collection and stem cells and socio demographic characteristics of the studied sample at different times of assessment $(n=53)$

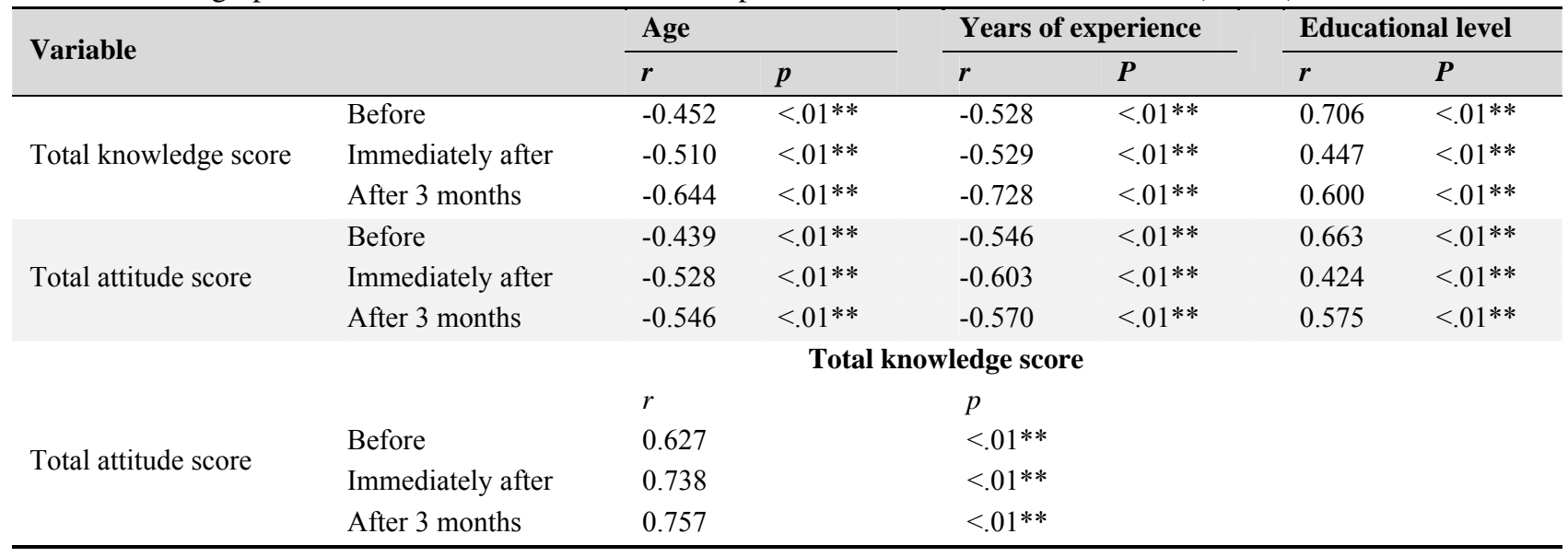

**Correlation is highly significant at $(P \leq .01)$

\section{Discussion}

This study was carried out to evaluate the effect of an educational intervention on maternity nurses' knowledge and attitude regarding cord blood collection and stem cells. As regard characteristic of the studied sample, it was found that more than half of nurses were aged from 20-25 years with a mean age of $25.34 \pm 4.51$ years. As far as nurses' qualifications, majority of them had diploma degree in nursing. Regarding years of experience in delivery room about two thirds of nurses with a mean of $6.36 \pm 2.75$ years. Only $1.9 \%$ of nurses attended training courses about cord blood collection and stem cells. In this respect Said ${ }^{[22]}$ who mentioned that about half of nurses' ages were ranged 20-30 years, the majority of them held diploma degree in nursing. In addition, nearly half of nurses had experience less than ten years in the labour ward.

On assessing knowledge of the studied sample regarding cord blood collection and stem cells, the findings of the current study revealed that the studied nurses had poor knowledge about cord blood collection and stem cells before the educational intervention, their low scores of knowledge may be attributed to the fact that cord blood collection and stem cells are new advanced trend and the nursing schools curriculum, especially the secondary level schools are still deficient in this issue. As well as after graduation, nurses neglect reading updating their professional knowledge besides lack of motivation. Therefore, such the diploma nurses constituted the majority of the study sample; it was expected to find such low level of knowledge.

Published by Sciedu Press
Meanwhile, immediately post-test and after three months of implementing the educational intervention, there was a statistically significant improvement for knowledge scores in relation to umbilical cord, cord blood collection, stem cell, and technique of cord blood collection and the majority of them had good knowledge. Such improvement might be accounted on nurses' interest to learn and acquire knowledge about the study topics as well as the written booklet distributed to nurses used as an ongoing reference, which was helpful in nurses' acquisition of knowledge. In addition, the application of adult learning rules throughout the educational sessions with encouragement of questions, participation, and interactions along the intervention as well as the use of multimedia.

The present study findings are in congruence with Elizebeth $^{[23]}$ who mentioned that the planned teaching programme was effective in improving the knowledge of staff nurses from pre test median score (20.1) to the post test (40.5). Also Lovis ${ }^{[24]}$ found that the majority of staff nurses have poor knowledge in the pre-test. Whereas in the posttest, most of the staff nurses had good knowledge regarding cord blood collection and stem cells and its utilization. In addition, these results are consistent with Kumaraswamy and Muthulakshmi ${ }^{[25]}$ who found that post-test score (mean: $39.6 \pm 2.57$ ) was higher than that of pre-test score (mean: $13.23 \pm 3.88$ ), and concluded that the structured teaching program was effective in enhancing the knowledge of health professionals especially staff nurses regarding umbilical cord blood stem cells collection, preservation and utilization and the teaching programme had a role in improving 
the knowledge of the health professionals. By educating the health care professionals especially nurses, misconceptions can be removed and adequate knowledge can be provided to them.

Moreover, Akshatha ${ }^{[26]}$ reported a significant difference between the pre-test and post-test level of knowledge and concluded that structured teaching program was effective in improving the knowledge of staff nurses regarding placental stem cell banking. These findings are supported by Armson $^{[27]}$ who emphasized that perinatal care provider should be informed and taught about the promising clinical potential of hematopoietic stem cells in umbilical cord blood and about current indications for its collection, storage and use based on sound scientific evidence.

The decline in the mean scores of nurses' knowledge after three months is normal and expected finding. This is known as retained of knowledge gained with time. However, these scores remained higher, compared to before intervention. These findings are consistent with Emery et al. ${ }^{[28]}$ who noticed a direct relationship between memory attrition and length of time that elapsed after exposure to certain educational events.

Concerning nurses' attitude towards cord blood collection and stem cells, the findings of the current study revealed that about two thirds of the studied nurses had negative attitude toward cord blood collection and stem cells before intervention. On the other hand, immediately and after three months of intervention the percentage changed to more than two thirds of the studied nurses had positive attitude toward cord blood collection and stem cells. This could be due to the fact that, receiving information from educational intervention and high adherence with educational sessions and their active participation improving their knowledge and lead to positive attitude. These findings are in the same line with Vincent. ${ }^{[29]}$ On the contrary, Bombas et al., ${ }^{[30]}$ who reported that nurses' attitudes in their study showed least significant improvement and added there were difficulties in changing attitudes.

In general, the nurses in the present study demonstrated poor knowledge, with high negative attitude. Implementing educational intervention that met their needs proved successful in fostering their knowledge and improving their attitudes, thus leading to acceptance of the research hypothesis. The effectiveness of the educational intervention and its independent positive influence on nurses' knowledge and attitude towards cord blood collection and stem cells was apparent from the results. The findings are in congruence with the results of Chen and Lou, ${ }^{[31]}$ systematic review that revealed that such programs are beneficial as they involve multi-dimensional teaching strategies. Furthermore, Varghese $^{[16]}$ added that nurses have an important role in imparting knowledge, therefore, the nursing curriculum should include the current technologies to update the knowledge regarding recent advances in addition to structured teaching programme is one of the effective methods to acquire and impart knowledge.

Regarding integrating knowledge into attitude, the present study demonstrated a positive statistically significant correlation between knowledge and attitude, with improved knowledge being associated with positive attitude. This finding is quite expected and is consistent with Askarian et $a l .{ }^{[32]}$ who reported a linear positive correlation between knowledge and attitude scores of studied nurses.

Additionally, the findings of the current study illustrated that there was a negative statistically significant correlation between total knowledge, total attitude scores and age, as well as between total knowledge, total attitude scores and years of experience at different times of assessment. This might be due to nurses who have more experience will be responsible for administrative and managerial activities.

\section{Conclusion}

In the light of the study findings, it can be concluded that there was a statistically significant improvement in nurses' knowledge mean scores, immediately, and three months after intervention, as well as there was a statistically significant difference in nurses' attitude scores before, immediately, and three months after intervention. The implementation of an educational intervention was effective and significantly improved nurses' knowledge and attitude towards cord blood collection and stem cells. Furthermore, the above mentioned findings proved and supported the research hypothesis.

\section{Recommendations}

- Adequately planned in-service training programs related to cord blood collection and stem cells must established to develop nurses' knowledge, attitude, and practices in order to fit newly developed concepts in care.

- The nursing curriculum should include the current technologies to update the knowledge regarding recent advances as stem cells.

- Simple booklets regarding cord blood collection and stem cells should be available and easily access in labour units.

- The study can be replicated on a larger sample in multicenter settings for generalizing the findings.

\section{Acknowledgements}

The authors express their gratitude and thanks towards all who have directly or indirectly helped them to complete this study and their support in each major step of the study.

\section{Conflicts of Interest Disclosure}

The authors declare that there is no conflict of interest statement. 


\section{References}

[1] Lowdermilk, D., Perry, S., Cashion, M., and Alden, K . Maternity and women's healthcare. 10th ed. Mosby Elsevier, Philadelphia. $2012 ; 26$.

[2] Aznar, J., and Sanchez, L. Embryonic stem cells: are useful in clinic treatments? J Physiol Biochem. 2011; 67(1): 141-144. PMid:21246421 http://dx.doi.org/10.1007/s13105-010-0 064-0

[3] American College of Obstetricians and Gynecologists. FAQ 172. Cord blood banking. 2011. Available from: http://www.acog.org/ /media/For\%20Patients/faq 172. pdf? dmc $=1 \& t s=20130225 \mathrm{~T} 2106314077$.

[4] Gluckman, E., Ruggeri, A., Volt, F., Cunha, R., Boudjedir, K., and Rocha, V. Milestones in umbilical cord blood transplantation. British Journal of Haematology. 2011; 154(1): 441-447. PMid:21726206 http://dx.doi.org/10.1111/j.1365-2141. 2011.08598.x

[5] Nietfeld, J., Pasquini, M., Logan, B., Verter, F., Horowitz, M Lifetime probabilities of hematopoietic stem cell transplantation in the U.S. Biological Blood Marrow Transplant. 2008; 14(3): 316-322. PMid:18275898 http://dx.doi.org/10.1016/j.bbm t.2007.12.493

[6] Broxmeyer, H. Umbilical Cord Blood Transplantation: Epilogue. Wagner, J.E. Seminars in Hematology. 2010; 47: 97103. PMid:20109617 http://dx.doi.org/10.1053/j.semin hematol.2009.10.002

[7] Fannin, M. Personal stem cell banking and the problem with property. Social and Cultural Geography. 2011; 12(4): 339-356. http: //dx.doi.org/10.1080/14649365.2011.574795

[8] Alicia, B., and Marcus, M. Placental stem cells in embryonic and fetal development. Reproductive sciences. 2009; 16(2): 178-187.

[9] National Institutes of Health, U.S. Department of Health and Human Services. Stem cell information: Current research. 2012. Available from: http://clinicaltrials.gov/ct2/results?ter $\mathrm{m}=$ stem+cells\&pg $=1$

[10] Ezzone, S. History of hematopoietic stem cell transplantation. Seminars in Oncology Nursing. 2009; 25(2): 95e-99e. PMid:19411011 http://dx.doi.org/10.1016/j.soncn.2009.03.004

[11] Zhong, X., Zhang, B, Asadollahi, R, Low, S., Holzgreve, W. Umbilical cord blood stem cells: what to expect. Annals of the New York Academy of Sciences. 2010; 1205(1): 17-22. PMid:20840248 http://dx.doi.org/10.1111/j.1749-6632.2010.05659.x

[12] Dinc, H., and Sahin, N. Pregnant women's knowledge and attitudes about stem cells and cord blood banking. International Nursing Review. 2009; 56(2): 250-256. PMid:19646176 http://dx.doi.org $/ 10.1111 / j .1466-7657.2008 .00689 . x$

[13] Waller-Wise, R. Umbilical cord blood: information for childbirth educators. Journal of Perinatal education. 2011; 20(1): 54-60. PMid:22211060 http://dx.doi.org/10.1891/1058-1243.20 .1 .54

[14] Chandran, B. Umbilical cord blood banking. 2012. Available from: http://www. essortment. com/au/cordbloodbanking.htm.

[15] Ikuta, L. Human umbilical cord blood transplantation: What nurses need to know. AACN Advanced Critical Care. 2008; 19(3): 264-267. PMid:18670200 http://dx.doi.org/10.1097/01.AA $\mathrm{CN} .0000330376 .11272 .8 \mathrm{~b}$

[16] Varghese, S. Effectiveness of structured teaching programme on stem cell therapy among fourth year B. SC. nursing students in selected nursing college at Mangalore. Published M. Sc. nursing thesis submitted to Rajiv Gandhi University of Health Sciences Karnataka, Bangalore. 2013; 20.
[17] Abdullah, Y. Cord Blood Banking: What nurses and healthcare providers should know, American Journal of Maternal Child Nursing. 2011; 36(6): 334-350. PMid:21918487 http://dx.doi.org $/ 10.1097 /$ NMC. $0 b 013$ e31822db253

[18] Cooper, C. and Severson, M. Cord Blood and Tissue Banking: Supporting Expectant Parent's Decision Making, International Journal of Childbirth Education. 2013; 28(2): 62-68.

[19] Harris, D., Badowski, M., Ahmad, N. The potential of cord blood stem cells for use in regenerative medicine. Expert Opinion on Biological Therapy. 2007; 7(22): 1311-1322. PMid:17727322 http: //dx.doi.org/10.1517/14712598.7.9.1311

[20] Rucinski, D., Jones, R., Reyes, B., Tidwell, L., Phillips, R., Delves, D. Exploring opinions and beliefs about cord blood donation among Hispanic and non-Hispanic black women. 2010; 50(5): 1057-1063.

[21] Staba-Kelly, S., Parmar, S., Delima, M., Robinson, S., Shpall, E. Overcoming the barriers to umbilical cord blood transplantation. Cytotherapy. 2010; 12(2): 121-130. PMid:20196692 http: //dx.doi.org/10.3109/14653240903440111

[22] Said, S. Effect of guideline about ethics on nurses' knowledge, performance and attitude in obstetric and gynecological department at Benha university hospital, Unpublished Ph. Sc. Nursing thesis submitted to faculty of nursing, Benha University. 2011; 82.

[23] Elizebeth, L. A study to assess the knowledge and attitude of various health professionals regarding placental stem cell and its utilization. Published M. Sc. Nursing thesis submitted to Rajiv Gandhi University of Health Sciences Karnataka. 2005; 56.

[24] Lovis, V. A study to evaluate the effectiveness of self instructional module on knowledge of placental stem cell and its utilization among staff nurses in selected hospitals at Mangalore. Published M. Sc. Nursing thesis submitted to Alva's college of nursing Moodbidri, Rajiv Gandhi University of Health Sciences Karnataka, Bangalore. $2010 ; 60$.

[25] Kumaraswamy, S., Muthulakshmi, P. Umbilical cord stem cell collection, preservation, and utilization. Nightingale Nursing Times. 2010; 6(1): 7-16

[26] Akshatha, R. Effectiveness of structured teaching programme on knowledge regarding placental stem cell banking among staff nurses working in selected maternity hospitals, Mangalore. Published M. Sc. Nursing thesis submitted to Rajiv Gandhi University of Health Sciences Karnataka. 2012; 46.

[27] Armson, E. Umbilical cord blood banking: implications for perinatal care providers. Journal of Obstetrics and Gynaecology. 2005; 27(3): 263-290.

[28] Emery, S., Labeeb. S. Marzouk, S. and Hussien, A. An In-service Training Program about Nursing Care of children with poisoning at Emergency Unit. Egyptian Nursing Journal. 2013; 4(1): 60-74.

[29] Vincent, V. A study to assess the effectiveness of self-instructional module on knowledge and attitude of staff nurses regarding umbilical cord blood stem cells at selected hospitals in tumkur" Bharathi College Of Nursing, Published M. Sc. Nursing thesis submitted to Rajiv Gandhi University of Health Sciences Karnataka. 2012; 33.

[30] Bombas, T., Costa, R., Palma. F., Vicente, L., Nogueira, A., and Andrade, S. Knowledge, attitude and practice survey among Portuguese gynaecologists regarding combined hormonal contraceptives methods. Eur J Contracept Reprod Health Care. 2012; 17(2): 128-134. PMid:22200109 http://dx.doi.org/10.3109/13625 187.2011 .631622

[31] Chen C., and Lou M. The effectiveness and application of mentorship programmes for recently registered nurses: a systematic review. J Nurs Manag. 2013.

[32] Askarian, A., Memish, Z., and Khan, A. Knowledge, practice, and attitude among Iranian nurses, midwives, and students regarding standard isolation precautions. Infection Control and Hospital Epidemiology. 2007; 28(2): 123-127. PMid:17265414 http://dx.d oi.org/10.1086/510868 